\title{
PENDIDIKAN AGAMA ISLAM MULTIKULTURAL DALAM INTERAKSI SOSIAL MASYARAKAT DI LABAN
}

\author{
Abdulloh Arif Mukhlas \\ STAI Al-Azhar \\ Email : abdulloharif.m@gmail.com
}

\begin{abstract}
Abstrak
Penelitian tentang Pendidikan Agama Islam Multikultural dalam hubungan interaksi sosial masyarakat multikultural di Laban ini menggambarkan tentang interaksi sosial masyarakat Laban yang memiliki nilai pendidikan terhadap anak-anak dan generasi penerus.Temuan dalam penelitian ini adalah; 1) adanya pembentukan karakter multikultural masyarakat Laban melalui kebiasaan meniru tradisi yang berlaku dari nenek moyang dan meniru apa yang dilakukan dan diperintahkan orang tua. 2) belum terdapat keseimbangan antara pembelajaran literal/tekstual, dengan kontekstual. Dari temuan tersebut, dapat diambil pelajaran dalam pengembangan teori pendidikan sebagai berikut: 1) multikulturalisme dalam karakter masyarakat akan lebih baik jika lebih sering mengadakan kegiatan interaksi sosial bersama. 2) perlu adanya keseimbangan antara teks dan konteks untuk menghasilkan pendidikan yang moderat. Karena pendidikan yang dilaksanakan melalui pengalaman dan pemberian contoh dari realitas akan menghasilkan pengertian yang realistis, namun belum terdapat penjelasan yang rinci. Sedangkan pengembangan pendidikan yang dilaksanakan melalui pemahaman dan penyampaian materi sesuai literatur akan menghasilkan pengetahuan teoritis, belum menjamin sesuai dalam implementasinya dalam realita.
\end{abstract}

Kata kunci: pendidikan, agama Islam, multikultural, interaksi sosial

\section{Abstract}

The study of Multicultural Islamic Education in the multicultural society's social interaction relationship in Laban illustrates the social interactions of the people of Laban which have educational values of children and succeding generations. The findings of this study are; 1) the existance of the multicultural character of the people of Laban through the habit of imitating the prevailing traditions of ancestors and imitating what parents do and commanded. 2) there is no balance between literal / textual with contextual learning. From these findings, can be taken lesson in the education theory as follows: 1) multiculturalism in the character of society will be better if more often conduct social interaction activities. 2) There is a need for a balance between text and context to produce moderate education. Because 
the education that is conduct through experience and giving examples of reality will produce a realistic understanding, but there is no detailed explanation yet. Meanwhile, the development of education conducted through the understanding and delivery of material according to the literature will generate theoretical knowledge, has not guaranteed appropriate in its implementation in reality.

Keywords: education, Islam, multiculturalism, social interaction

\section{PENDAHULUAN}

Laban adalah sebuah desa yang berada di daerah kecamatan Menganti, kabupaten Gresik, yang berada di dekat perbatasan dengan kota Surabaya. Desa yang memiliki masyarakat multikultur, terdiri dari penduduk yang beragama Islam sebagai mayoritas agama, sebagian penduduk beragama Hindu dengan aktifitas keagamaan dan budayanya, ada juga penduduk yang beragama kristen, dan sebagian kecil terdapat aliran kebatinan. Perbedaan tersebut, terdapat beberapa yang ditemukan masih dalam satu lingkungan keluarga dekat, hubungan ayah dan anak, kakak dan adik.

Meski berbeda agama, toleransi yang terjadi diantara masyarakat desa Laban sangat tinggi. Pengajian-pengajian yang digelar warga Muslim kebanyakan tidak menyinggung ajaran agama lain apalagi sampai menyinggung kejelekan agama atau penganut agama lain. Kerukunan warga tampak makin nyata saat ngembak geni, lebaran umat Hindu setelah sehari semalam menjalani catur brata penyepian. Sama seperti saat pawai ogohogoh yang diramaikan oleh semua kalangan masyarakat, Dusun Laban Kulon kembali ramai oleh warga yang saling unjung-unjung, bertandang dari satu rumah ke rumah lain. Dalam kegembiraan dan kebersamaan, demikian sebagian penjelasan dari salah satu informan.

Diantara keunikan yang menarik adalah, perkampungan yang terdapat bangunan pura sebagai sentral kegiatan keagamaan justru dihuni oleh masyarakat mayoritas Muslim, sedangkan bangunan masjid yang menjadi salah satu tempat utama kegiatan keagamaan umat muslim berada di lingkungan masyarakat Hindu. Meskipun demikian tanda-tanda persetruan maupun perselisihan tidak tampak dalam kehidupan sehari-hari. Perasaan terganggu dengan kegiatan keagamaan juga tidak pernah terlontarkan..

Tidak ada pembatasan hubungan antara anak, pemuda Hindu dengan Muslim dengan kristen bahkan katolik sekalipun dengan LDII, sekolah nya pun sama. Jadi kalau pelajaran agama Islam yang Hindu keluar, demikian pula sebaliknya, jadi saling menghormati. LDII juga demikian, saling 
membantu, kalau Hindu ada acara LDII juga mengerahkan untuk membantu.

Apa yang disampaikan informan tersebut menunjukkan adanya pembelajaran toleransi yang ditanamkan sejak masih anak-anak. Mereka terbiasa belajar dan bermain bersama. Setiap hari anak-anak mereka belajar bersama dalam satu lembaga pendidikan formal mereka sejak di Sekolah Dasar (SD), SMP bahkan tidak jarang juga yang sampai SMA masih bareng dalam satu naungan lembaga yang sama. Mereka juga sering bertemu bersama dalam belajar kelompok, les atau kegiatan-kegiatan Desa.

Salah satu keterangan yang disampaikan informan di saat peneliti melakukan wawancara dan meminta keterangan tentang lembaga pendidikan anak-anak di Laban, dan kegiatan pembelajaran masa kanakkanak, informan menyampaikan beberapa hal sebagai berikut: Warga Islam gadah TK, warga Hindu nggih gadah TK, sekolah TK seng umum nggih wonten. Anak tiyang Islam mlebet TK tiyang Hindu nggih mboten noponopo, tiyang Hindu ten tiyang Islam nggih mboten nopo-nopo. (Warga Islam mempunyai TK, warga Hindu juga mempunyai TK, sekolah TK yang umum juga ada. Anak orang Islam masuk TK milik orang Hindu juga tidak apa-apa, orang Hindu ke orang Islam juga tidak apa-apa).

Pertemanan yang terjalin antara anak-anak masyarakat Laban, seagama maupun beda agama, lembaga pendidikan yang dibangun oleh warga Hindu, bahkan tempat ibadah dan sarana dakwah serta pendidikan lainnya menunjukkan adanya kehidupan yang damai. Semua tersebut bisa menjadi contoh dan ditiru anak-anak generasi selanjutnya sebagai bentuk mempertahankan dan membentuk budaya masyarakat. Hal tersebut dikuatkan juga dengan keterangan yang disampaikan informan salah satu tokoh masyarakat bahwa warga Hindu sudah ada sejak sebelum tahunn 1965.

Keterlibatan anak-anak dalam melaksanakan shalat di halaman rumah orang Hindu, merayakan hari raya bersama-sama dengan orang Hindu, ater-ater kepada orang Hindu adalah pembelajaran bagaimana kita saling menolong, menghormati dan balas budi terhadap orang lain, yang berbeda sekalipun. Demikian juga banyak anak-anak yang melihat proses pembuatan ogoh-ogoh. Bahkan ada juga yang ikut mengiring dan mengangkat ogoh-ogoh. Tidak ada larangan dari orang tuanya. Kebebasan tersebut akan tertanam dalam karakter anak sebagai pendidikan saling mendukung dan bertoleransi.

Dari paparan fenomena sosial yang terkait dengan interaksi sosial masyarakat di Laban, maka menarik untuk dipelajari cara masyarakat mendidik generasinya untuk mempertahankan kerukunan dan kebersamaan antar umat beragama melalui cara mereka berinteraksi. 


\section{METODE PENELITIAN}

Penelitian tentang pendidikan Agama Islam multikultural dalam interaksi sosial masyarakat Di Laban ini dilakukan dengan jenis penelitian kualitatif. ${ }^{1}$ Dengan menggambarkan fenomena sosial masyarakat Laban secara holistik, dari data yang dihasilkan melalui observasi dan wawancara baik berupa dokumentasi, kata-kata maupun laporan terinci dari pandangan informan dan melakukan studi pada situasi yang dialami, dilakukan dalam kondisi alamiah yang bersifat penemuan atau eksplorasi dan menetapkan peneliti sebagai instrumen, serta melakukan analisa data secara induktif. ${ }^{2}$

Penelitian $^{3}$ ini menggunakan pendekatan interaksionisme simbolik. Dalam pandangan Weber, perilaku manusia yang terjadi merupakan konsekwensi dari sejumlah pandangan atau doktrin yang terdapat di benak pikiran pelakunya. Jadi, terdapat sejumlah pengertian, batasan dan kompleksitas makna yang berkembang di dalam pikiran manusia sebagai pelaku, yang kemudian membentuk perilaku yang diekspresikan secara eksplisit.

Ada 3 hal penting dalam interaksionisme simbolik menurut filsafat pragmatis :

1. Memusatkan perhatian pada interaksi antar aktor dan dunia nyata.

2. Memandang aktor maupun dunia nyata sebagai proses dinamis dan bukan struktur yang statis.

3. Arti penting yang menghubungkan kepada kemampuan aktor untuk menafsirkan kehidupan sosial.

\section{PEMBAHASAN}

\section{Pendidikan Islam Multikultural}

Dalam pandangan teori behavioristik belajar adalah perubahan tingkah laku yang dihasilkan dari pengalaman (Gage, Berliner, 1984). Belajar merupakan bentuk dari akibat terjadinya interaksi antara stimulus dan respon (Slavin, 2000). Seseorang dianggap telah belajar tentang sesuatu jika didapati di dalam dirinya adanya perubahan dalam perilakunya.

${ }^{1}$ Sugiono. Metode Penelitian Pendidikan Pendekatan Kuantitatif, Kualitatif dan RAD. (Bandung: Alfabeta. 2007), 76, dan lihat

Robert C. Bogdan dan Sari Knopp Biklen. Qualitative Research for education: An Introduktion to Theory and Methods. (Boston: Alyn and Bacon, Inc. 1998), 78.

${ }^{2}$ John W. Creswell, Penelitian Kualitatif \& Desain Riset. (Yogyakarta: Pustaka Pelajar, 2013), 15.

${ }^{3}$ Lexy J Moleong, 1999. Metodologi Penelitian Kualitatif. (Bandung: Remaja Rosdakarta, 1999). 65. 
Skinner (1958) memberikan definisi belajar "Learning is a process of progressive behavior adaptation". Definisi tersebut menyampaikan bahwa belajar itu merupakan suatu proses adaptasi perilaku yang bersifat progresif. $^{4}$

Pendidikan menurut Khaldun bukanlah semata-mata suatu aktifatas yang bersifat pemikiran yang jauh dari aspek pragmatis dalam kehidupan, akan tetapi pendidikan juga merupakan gejala sosial yang menjadi ciri khas dan watak jenis manusia. Sehingga proses belajar mengajar atau pendidikan untuk mendapatkan ilmu pengetahuan merupakan hal yang alami di tengah umat manusia karena tuntutan kehidupan dan tabiat dari bawaan akal.

Pendidikan Islam oleh Marimba dipahami sebagai bimbingan jasmani dan rohani berdasarkan hukum-hukum agama Islam menuju pada terbentuknya kepribadian utama menurut ukuran Islam. Pengertian tersebut sangat jelas bahwa pendidikan Islam diartikan sebagai bentuk bimbingan terhadap jasmani dan sekaligus rohani yang menggunakan aturan menurut hukum agama Islam menuju terbentuknya karakter dan kepribadian yang mulia menurut Islam. (Shofan, 2004). ${ }^{5}$

Khaldun membagi materi pendidikan yang menjadi salah satu komponen operasional pendidikan menjadi dua macam bagian;

1. Ilmu-ilmu naqliyah, adalah ilmu yang bersumber dari al Quran dan Hadits yang dalam hal ini peran akal hanya sebagai mediator menghubungkan cabang-cabang permasalahan dengan pokok utamanya sebagai otoritas syariat yang diambil dari al Quran dan Hadits, diantaranya adalah nilai-nilai ibadah.

2. Ilmu-ilmu Aqliyah, adalah ilmu yang bersifat alami bagi manusia yang diperoleh melalui proses berfikir, sehingga keberadaan ilmu ini bersamaan dengan wujudnya peradaban kehidupan manusia, umumnya ilmu-ilmu yang berhubungan dengan kegiatan sosial. ${ }^{6}$

Untuk menumbuhkan skill peserta didik, masih dalam pandangan Khaldun, tidak cukup dengan faham dan hafal kaidahkaidah ilmiyahnya, namun dengan cara sering mengulang dengan memperbanyak contoh dan pembiasaan. ${ }^{7}$

${ }^{4}$ Khairuman, Model Pendidikan Inklusif, (Jakarta: Mahisa Media Utama, 2014), 65.

${ }^{5}$ Moh Yamin, Vivi Auliya. Meretas Pendidikan Toleransi, Plurasisme dan Multikulturalisme Keniscayaan Peradaban. (Malang: Madani Media, 2011), 56 2011). 76.

${ }^{6}$ Ahmadie Thoha, Muqaddimah Ibn Khaldun, terjemah. (Jakarta: Pustaka Firdaus, ${ }^{7}$ Ibid. 
Pendidikan agama multikultural adalah pendidikan penekanannya terdapat pada nilai-nilai moral, seperti tolong menolong terhadap sesama, menghargai keberagaman dan mengedepankan sikap yang menjunjung kemanusiaan. ${ }^{8}$ Hal ini seperti yang disampaikan dalam Al Quran surat al Ma'idah ayat 2.

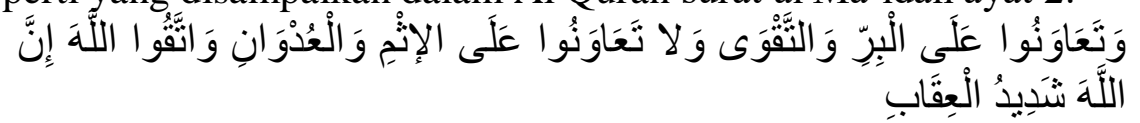

"Dan tolong-menolonglah kamu dalam (mengerjakan) kebajikan dan takwa, dan jangan tolong-menolong dalam berbuat dosa dan pelanggaran. dan bertakwalah kamu kepada Allah, Sesungguhnya Allah amat berat siksaNya".

a. Multukulturalisme dan nilai multikultural

Multikulturalisme adalah sebuah konsep pemikiran terhadap keberagaman budaya yang hidup bersama tanpa mempermasalahkan perbedaan yang terjadi. Akan tetapi, pengakuan dan akomodasi positif terhadap perbedaan juga dibutuhkan melalui pemenuhan hak-hak kelompok yang berbeda (Kymlicka, 1995). ${ }^{9}$

Di dalam masyarakat multikultural terdapat nilai-nilai pemikiran yang menjadi asas konsep pemikiran tersebut yang akan mengantarkan arah dari tujuan pemikiran multikulturalisme. Beberapa nilai yang terdapat didalam multikultural adalah $A t$ Ta'addudiyyah, Al Musawah, Al 'Adalah, At Tanawwu', At Tasamuh, At Ta'awun dan Al Ikhtilaf.

a) At Ta'addudiyyah

At Ta'addudiyyah, pluralitas dalam kehidupan adalah bagian dari kehendak Allah SWT. Diantara ayat Al Qur'an yang menjelaskan adanya pluralism adalah Surat Al Kahfi ayat 29

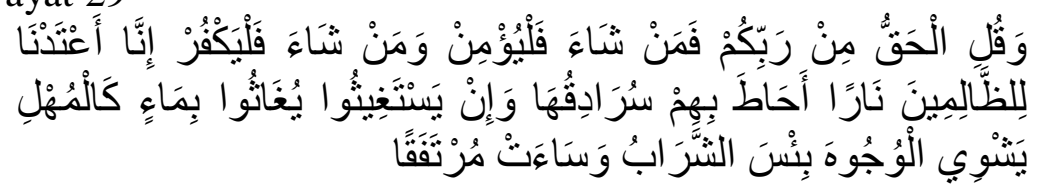

Dan Katakanlah: "Kebenaran itu datangnya dari Tuhanmu; Maka barangsiapa yang ingin (beriman)

${ }^{8}$ Yaya Suryana dan A Rusdina. Pendidikan Multikultural, Konsep, Prinsip dan Implementasi. (Bandung: Pustaka Setia, 2015). 322.

${ }^{9}$ Khairruman, Op.Cit, 76. 
hendaklah ia beriman, dan barangsiapa yang ingin (kafir) Biarlah ia kafir". Sesungguhnya kami Telah sediakan bagi orang orang zalim itu neraka, yang gejolaknya mengepung mereka. dan jika mereka meminta minum, niscaya mereka akan diberi minum dengan air seperti besi yang mendidih yang menghanguskan muka. Itulah minuman yang paling buruk dan tempat istirahat yang paling jelek.

\section{b) Al Musawah}

Al Musawah, keragaman dan bermacam-macam setatus dan kedudukan manusia dalam menjalani kehidupan sosial tetap memiliki nilai kesamaan di sisi Allah, kesamaan derajat dan potensi untuk berlomba saling mendapatkan kemuliaan disisi-Nya. Disampaikan oleh hadits riwayat Imam Muslim dalam Tafsir Ibnu Katsir sebagai berikut;

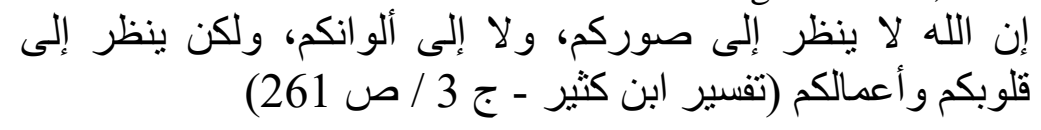

"Allah tidak melihat kalian semua dari bentuk dan warna kalian melainkan Allah melihat kepada hati dan perbuatan kalian" (HR Muslim 2564)

$$
\text { وَلَقَذْ كَرَّمْنَا بَنْي آدَمَ }
$$

"dan Sesungguhnya telah Kami muliakan anak-anak Adam," (Q.S Al Isro' 70)

c) Al 'Adalah

Al 'Adalah, kebijakan yang tidak membedakan berdasarkan perbedaan suku, ras, golongan karena Allah melihat manusia dari sisi nilai ketaqwaannya bukan dari sisi suku atau golongannya. Hal tersebut adalah bagian dari nilai multikulturalisme yang ditanamkan.

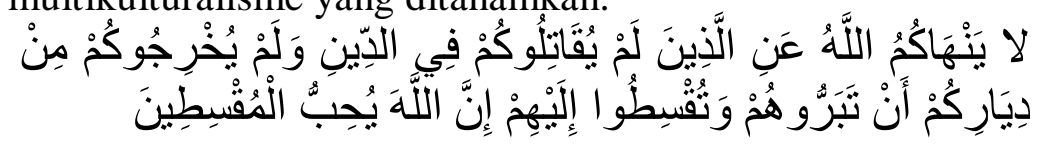

:Allah tidak melarang kamu untuk berbuat baik dan berlaku adil terhadap orang-orang yang tiada memerangimu karena agama dan tidak (pula) mengusir kamu dari negerimu. Sesungguhnya Allah menyukai orang-orang yang berlaku adil" (QS al Mumtahanah, 8). 
d) At Tanawwu'

At Tanawwu', bermacam-macamnya budaya yang lahir karena tuntutan kebutuhan hidup manusia yang berbeda-beda, dalam tuntutan lingkungan yang berbeda. Hal ini tidak bisa dipungkiri, sehingga adanya keberagaman dalam kehidupan adalah bukti jelas pengakuan adanya multikultural dalam kehidupan.

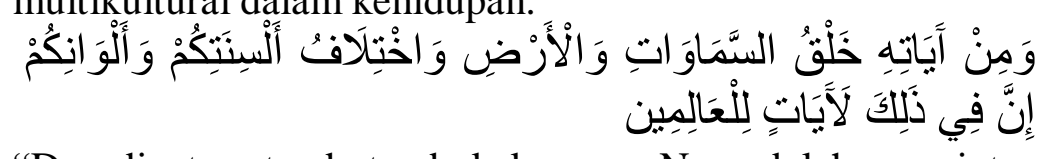

"Dan diantara tanda-tanda kekuasaan-Nya adalah menciptakan langit dan bumi dan berlain-lainan bahasamu dan warna kulitmu. Sesungguhnya pada yang demikian itu benar-benar terdapat tanda-tanda bagi orang yang mengetahui”. (QS. alRûm; 22).

e) At Tasamuh

At Tasamuh, penanaman sifat toleransi terhadap sesama, sikap ramah dengan cara menghargai pendirian orang lain seperti pendapat, pandangan, kepercayaan, kebiasaan dan kelakuan yang berbeda atau bertentangan dengan pendirian diri sendiri. Tasamuh ini tidak harus mengakui kebenaran pihak lain, namun cukup memberi kesempatan mereka untuk menjalani yang dia anggap benar selama tidak merugikan pihak lain.

Dalam urusan agama, Islam mengajarkan untuk memberi kebebasan kepada semua penganut agama dalam melaksanakan agama dan kepercayaannya. Hal ini disampaikan oleh Allah dalam Al Qur'an

$$
\text { لَكُمْ دِينُكُمْ وَلِيَ دِين }
$$

“untukmu agamamu, dan untukkulah, agamaku." (al Kafirun, 6).

f) At Ta'awun

At Ta'awun, saling tolong menolong adalah modal untuk hidup saling rukun dalam strata sosial yang berbedabeda. Kelemahan manusia dalam satu sisi akan membutuhkan pertolongan dari pihak lain untuk mencapai tujuannya. Di lain waktu kelebihan yang ia miliki akan dibutuhkan pihak lain untuk menutupi kekurangannya. Demikian alur hidup yang telah digariskan. 


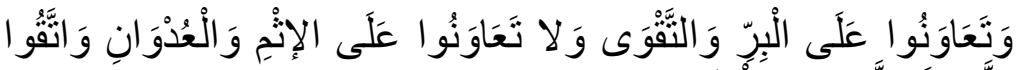

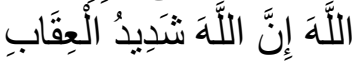

"Dan tolong-menolonglah kamu dalam (mengerjakan) kebajikan dan takwa, dan jangan tolong-menolong dalam berbuat dosa dan pelanggaran. dan bertakwalah kamu kepada Allah, Sesungguhnya Allah amat berat siksaNya" (QS al Maidah, 2).

\section{g) Al Ikhtilaf}

Al Ikhtilaf, perbedaan pendapat dan pandangan bukan sesuatu yang harus dihindari. Perbedaan tersebut bisa juga memperkaya hazanah keilmuan. Bahkan di dalam perbedaan terdapat kelonggaran untuk menentukan sikap dan pilihan yang sesuai dengan karakter yang dimiliki

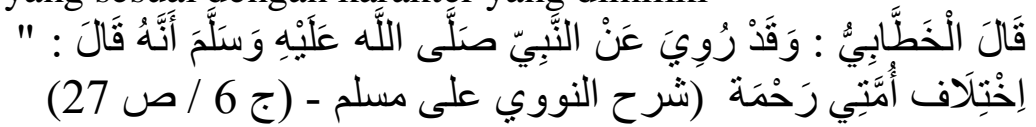

Berkata Imam al Khattabi, diceritakan dari beliau Nabi SAW. Perselisihan ummatku adalah rahmat. (an Nawawi, tt: 27)

Menurut A. Malik Fadjar dalam Muhaimin, ${ }^{10}$ di dalam Pendidikan Islam Multikultural terdapat tujuan dan harapan di dalam pembentukan masyarakat, baik di dalam segi kepribadian individu agar memiliki karakter akhlak karimah maupun dalam interaksi sosial masyarakat agar tercipta kehidupan yang damai sejahtera.

Kesadaran akan kesamaan hak terhadap sesamanya bisa menumbuhkan rasa saling menghargai, menjaga haknya, tidak saling menyakiti. Sama seperti kita tidak mau disakiti, kita juga tidak boleh menyakiti, mereka pun juga tidak mau disakiti dan tidak boleh menyakiti.

Melalui pendidikan Islam multukultural diharapkan dapat membentuk karakter umat yang bersikap toleransi. Karakter tersebut tidak lain adalah bagian dari tujuan utama pendidikan Islam, yaitu menanamkan dan membentuk sikap akhlakul karimah. Seperti yang disabdakan nabi;

$$
\text { وقال صلى الله عليه وسلم : بعثت لأتمم مكارم الأخلاق, }
$$

${ }^{10}$ Muhaimin. Wacana Pengembangan Pendidikan Islam. (Yogyakarta: Pustaka Pelajar, 2009), 47. 
"Saya diutus semata-mata untuk menyempurnakan akhlaq yang mulia" (Muhammad Al Qurthubi, tt, 7/345).

\section{Mengenal Nilai-Nilai Pendidikan Agama Islam Multikultural Masyarakat Desa Laban}

Pengakuan masyarakat atas adanya agama lain, penghormatan, keterbukaan dan kerja sama yang sudah tertanam sejak lama dan masih dipertahankan sampai sekarang adalah bentuk stimulus bagi generasi muda. Sehingga apa yang mereka lihat dari apa yang dilakukan pendahulunya adalah bentuk materi pembelajaran bagaimana melakukan hubungan interaksi sosial di masyarakat. Selanjutnya merubah karakter dan membentuk prilaku dalam interaksi sosial.

Baik yang Muslim maupun yang Hindu mereka memiliki nenek moyang yang sama. Karena pada awalnya nenek moyang masyarakat Laban dulunya adalah mengikuti ajaran Buda Jawi. Seiring dengan berjalannya waktu mereka ada yang pindah ke agama Islam dan ada yang mengikuti ajaran agama Hindu. Seperti yang disampaikan oleh salah satu informan; Saya juga ga ngerti duluan mana orang Islam sama Hindu, wong dulunya itu penganut Buda Jawi (W/20/Balai Desa/MHD/5 oktober 2018).

Karena mereka yang berbeda agama banyak diantaranya yang masih ada hubungan keluarga, maka sikap rukun, kebersamaan, tolong menolong, tidak saling mengganggu adalah panggilan dari hati.

Pengakuan tentang sikap tersebut disampaikan oleh salah satu warga muslim penjaga warung. Demikian penuturannya;

Sembarang nak.. ogoh-ogoh ngoteniku Islam nggih tumut nggotong nak. mboten nopo-nopo.. dados Islam nggih tumut gotong ogoh-ogoh ngoten. Ningali kegiatan ten pura nggih angsal..bah-bah.. mboten noponopo ningali ten pura. bebas. Ten mriki niku sembarang anak-anak koncoan kaleh tiyang Hindu (Terserah nak.. ogoh-ogoh begitu orang Islam juga ikut mengangkat.. tidak apa-apa. Jadi orang Islam juga ikut mengangkat ogoh-ogoh. Melihat kegiatan di pura juga boleh. Masa bodoh.. tidak apa-apa melihat di pura .. bebas. Di sini itu bebas anak-anak berteman dengan anak Hindu).

Ibu tersebut juga menyampaikan kalau pelanggannya atau yang membeli di warungnya tidak hanya orang Islam. Katah seng tumbas mriki. Mboten enten bedane..mboten beda-bedaake. Tiyang Islam nggih tumbas ten tiyang Hindu (Banyak yang membeli ke sini. tidak ada bedanya. Tidak membeda-bedakan. Orang Islam juga membeli ke orang Hindu).

Kebebasan dalam menjalankan agama tidak hanya bagi warga mayoritas, seperti suara sepeker menjelang shalat lima waktu, namun orang Hindu juga mendapatkan kebebasan beribadah, misalnya melantunkan kidung atau pujian menggunakan sepeker. Semua itu berjalan baik-baik saja. 
Tidak hanya dalam urusan agama, dalam urusan bisnis Muslim dan Hindu juga memiliki kesamaan hak. Di Laban, jual beli atau berlangganan tidak terikat dengan sesama agama. Mereka bebas menjual atau membeli kepada siapapun, kepada warga yang beda agama sekalipun.

Anak-anak juga mendapatkan kebebasan dalam menentukan pilihan. Memilih teman, memilih tempat belajar bahkan ada juga yang bebas dalam memilih pasangan hidup. Sikap diam orang tua atau tokoh agama dalam permasalah tersebut adalah bagian dari input atau stimulus yang bisa menimbulkan respon dan mempengaruhi atau membentuk kepribadian generasi yang lain. Dengan anggapan bebas menjalin hubungan terhadap lain agama dalam hal apapun.

Dapat disimpulkan bahwa masyarakat Laban mengetahui nilai-nilai multikultural melalui hubungan interaksi sosial sehari-hari, baik dalam keluarga, teman maupun dengan tetangga dan warga masyarakat yang lain.

\section{Membudayakan Pendidikan Agama Islam Multikultural dalam Interaksi Sosial}

Baik disengaja maupun tidak, budaya merubah karakter anak-anak melalui kegiatan atau tradisi di Laban banyak ditemukan. Diantaranya kegiatan sekolah, bermain maupun belajar. Kegiatan tersebut bisa menjadikan mereka sangat akrab dan tidak pernah mempermasalahkan perbedaan suku maupun agama. Keakraban tersebut berlanjut sampai masa tua dan dilanjutkan anak-anaknya. Mereka tahu adanya perbedaan namun tidak pernah mempermasalahkan perbedaan tersebut.

Sikap orang tua terhadap anaknya dalam memberikan kebebasan bergaul dengan siapapun adalah bentuk pembelajaran secara tidak langsung tentang adanya persamaan hak, pembelajaran bersikap baik terhadap siapapun dan tidak adanya diskriminasi sesama warga desa.

Sebagian warga Hindu yang rumahnya berada di sekitar masjid Sabilul Huda setiap tahunnya mempersilahkan halaman rumahnya untuk ditempati melaksanakan ibadah shalat 'id, baik 'idul fitri maupun 'idul adha. Setelah shalat 'idul fitri, para jamaah saling bersalaman, saling meminta maaf, termasuk kepada umat Hindu. Budaya tersebut sudah berjalan sejak lama.

Pembagian daging korban, salah satu bentuk ritual ibadah umat Islam yang dilaksanakan setelah shalat 'idul adha juga dibagikan terhadap masyarakat Hindu. Kebersamaan dan kepedulian ini telah berjalan bertahuntahun tanpa ada rintangan apapun.

Pelestarian budaya perayaan ogoh-ogoh yang terjadi setiap tahun selalu mendapatkan sambutan antusias dari masyarakat. Tidak pernah ada kejadian perusakan ogoh-ogoh atau mengganggu jalannya perayaan. 
Sambutan antusias masyarakat tidak hanya datang dari umat Hindu, masyarakat muslim juga ikut partisipasi dalam arak-arakan ogoh-ogoh. Hal ini dilakukan karena masyarakat umat Hindu juga memberikan apresiasi dalam setiap kegiatan umat muslim. Misalnya saat acara maulid nabi, perayaan lebaran, atau perayaan tahun baru hijriyah.

Budaya tahunan yang melibatkan semua unsur masyarakat juga menjadi perhatian dalam usaha merekatkan hubungan toleransi, misalnya peringatan hari kemerdekaan, peringatan hari besar nasional dan sedekah bumi.

Dengan adanya kegiatan sosial kemasyarakatan bersama, masyarakat Laban paham dan mengerti nilai-nilai multikultural yang harus dipertahankan, sehingga mereka semakin baik dalam menjalin hubungan kebersamaan, rukun dan saling tolong-menolong.

\section{Pendidikan Agama Islam multikultural yang dikembangkan dalam interaksi sosial masyarakat di Laban}

Masyarakat Desa Laban dengan kultur budaya dan agama yang berbeda bisa hidup bersama dalam kerukunan. Tercapainya kerukunan dalam kehidupan mereka merupakan salah satu indikasi terjalinnya hubungan baik diantara masyarakat dalam menjalani kehidupan dan interaksi sosialnya.

Kegiatan keagamaan umat Islam di Laban meliputi kegiatan keagamaan yang bentuknya kemasyarakatan, ritual keagamaan atau ibadah dan juga kegiatan pengajian untuk pengembangan wawasan agama.

Materi yang dikaji bisa bermacam-macam. Namun secara umum bisa digolongkan menjadi dua kategori seperti yang disampaikan oleh salah satu ustad dalam salah satu kesempatan wawancara dengan peneliti, yaitu urusan ibadah dan urusan hubungan sosial.

Di dalam kegiatan ritual keagamaan umat Muslim, nilai-nilai penghargaan terhadap penganut agama lain tetap menjadi perhatian. Misalnya di dalam kegiatan kirim doa, hanya umat Islam saja yang mengikuti kegiatan, namun berkat yang dibagikan juga diberikan kepada masyarakat non Muslim. Tradisi yang demikian ini adalah pembelajaran yang diberikan turun temurun.

Pembagian daging korban juga diberikan kepada masyarakat non Muslim yang mukim di sekitar lokasi masjid, karena mereka juga sering mempersilahkan halaman rumahnya untuk kegiatan keagamaan. Sehingga hubungan interaksi ini menjadi contoh para generasi muda untuk mempertahankan nilai-nilai multikultural. ${ }^{11}$

11 Muhammad Tholchah Hasan,. Pendidikan Multikultural Sebagai Opsi Penanggulangan Radikalisme. (Malang: Lembaga Penrbitan UNISMA, 2016). 45-46. 
Untuk membentuk karakter multikultur anak-anak, para orang tua sering melibatkan anak-anak untuk membeli kebutuhan kepada warga yang beda agama. Demikian juga sesekali menyuruh anaknya untuk mengantarkan pemberian kepada tetangga yang beda agama. Hal ini menumbuhkan pemikiran anak-anak bahwa beda agama tidak bisa dijadikan alasan untuk saling mengambil jarak dalam berinteraksi. Sehingga mereka tetap berteman baik, bermain, belajar bersama dengan anak-anak yang beda agama.

Dari paparan data tersebut terdapat beberapa hal yang unik dan menarik untuk dicermati melalui teori pembelajaran behavioristik. melalui sisi aspek stimulus dan respon dari interaksi masyarakat.

1. Stimulus

Di dalam interaksi sosial masyarakat di Laban, semua yang terjadi dari semua masyarakat, baik tokoh agama, tokoh masyarakat, warga maupun pejabat adalah bentuk materi pendidikan bagi yang menyaksikan. Meliputi perkataan, perbuatan dan sikap yang dilakukan, seperti perkataan, perbuatan dan sikap yang dilakukan beliau nabi adalah materi pendidikan bagi para shahabat Nabi. Bedanya, apa yang dilakukan atau datang dari beliau Nabi adalah nilai kebenaran yang tidak bisa ditawar, sementara yang datang dan dilakukan oleh masyarakat Laban masih sebatas subyektif yang membutuhkan penelitian mendalam.

Secara garis besar, masyarakat Laban telah mengkelompokkan kegiatan menjadi dua, ibadah dan sosial. Hal ini sesuai dengan teori dalam pendidikan Agama Islam multikultural yang membedakan sikap toleransi dalam urusan ibadah dan urusan sosial. Namun dalam kenyataannya, materi pendidikan yang disampaikan melalui tekstual tidak menyampaikan secara rinci batasan-batasan nilai ibadah dan nilai sosial, demikian juga contoh perilaku dari tokoh masyarakat maupun tokoh agama juga tidak bisa dipahami secara rinci, maka yang terjadi adalah perbedaan persepsi dalam menggolongkan sebuah kegiatan sebagai nilai ibadah atau nilai sosial. Sehingga masih terjadi adanya perkawinan beda agama yang dalam pendidikan Agama Islam adalah dilarang, terjadi beberapa masyarakat yang keluar dari agama Islam dan masih dalam beberapa kegiatan agama Islam, saling terlibat dalam kegiatan keagamaan.

2. Respon 
Di Laban kita bisa melihat dengan jelas kultur yang berbeda. Telah tertanam dalam karakter mereka hidup bersama dalam perbedaan. Mereka saling menjalankan keyakinan dan ajaran masing-masing sesuai dengan karakter dan ajarannya. Namun dalam kesempatan yang lain mereka terikat dalam satu kesamaan tradisi dan budaya atau kegiatan sosial kemanusiaan yang tidak terikat dengan salah satu agama atau tradisi tertentu.

Dengan kesadaran masyarakat Laban tentang keragaman kulturnya yang memiliki kesamaan hak, melahirkan corak kehidupan yang berwarna warni dalam satu kebersamaan dan kerukunan. Dibalik keragaman tersebut terdapat nilai-nilai multikultural dalam kehidupan sosial di desa Laban diantaranya adalah:

a. At Ta'addudiyyah

Pluralitas dalam kehidupan di masyarakat Laban tampak sekali. Di waktu menjelang malam mereka saling berpapasan untuk menjalankan ibadah masing-masing. Dengan sama-sama menggunakan pengeras suara mereka lantunkan bacaan-bacaan ritual keagamaan (pujian) masing-masing. Tanpa ada protes dari pihak lain, semua melaksanakan kegiatan masing-masing dalam jarak tempat yang berdekatan.

Namun terdapat hal yang perlu disikapi adalah, tidak terdapat batasan yang jelas antara kegiatan keagamaan dan kegiatan sosial. Sehingga ada diantara jenis kegiatan ritual keagamaan yang melibatkan warga agama lain, atau terdapat warga yang terlibat dalam kegiatan keagamaan agama lain.

b. Al Musawah

Keragaman budaya dan agama di Laban tidak sampai menimbulkan diskriminasi. Meskipun masyarakat Hindu dan Kristen merupakan masyarakat minoritas namun untuk menjalani kehidupan sosial mereka mendapatkan perlakuan yang sama. Pelanggan mereka dalam jual beli juga beragam. Orang Islam membeli kepada orang Hindu, demikian juga orang Hindu membeli kepada orang Islam.

Demikian juga dalam melaksanakan ritual keagamaan. Tidak ada batasan-batasan tertentu bagi minoritas dalam melaksanakan kegiatan keagamaan, baik yang bersifat ritual maupun pengembangan ajaran atau pendidikan. Semua masyarakat memiliki hak yang sama.

Kesamaan hak dalam sosial atau dalam melaksanakan ajaran agama masing-masing menimbulkan salah paham dalam 
memahami batasan-batasannya. Sehingga terjadi pemahaman kesamaan hak dalam segala apapun. Akibatnya terjadi adanya beberapa warga yang pindah agama atau nikah beda agama.

c. Al 'Adalah

Kebijakan dan perlakuan yang diberikan oleh pihak pemerintah desa terhadap masyarakat tidak membeda-bedakan karena perbedaan agama, suku, ras maupun golongan. Misalnya fasilitas lapangan oleh raga yang diberikan desa diperuntukkan untuk semua kalangan masyarakat. Teknis pelaksanaannya diserahkan kepada yang bersangkutan, terkadang mereka menggunakan bersama-sama meskipun beda agama. Tempat pemakaman, masing-masing agama memiliki tempat yang dipisahkan.

d. At Tanawwu' (Beragam)

Banyak sekali ragam budaya dalam kehidupan di Laban. Semua berjalan tanpa mendapat gangguan dari pihak lain. Keragaman budaya tersebut juga diketahui dan diakui keberadaannya oleh masyarakat. Keberadaan dan pengakuan atas perbedaan tersebut berjalan apa adanya sesuai dengan aturan dan ajaran masing-masing tanpa mencampur adukkan permasalahan. Sehingga tampak sekali cirikhas dan corak masing-masing budaya dan agama mereka.

Pembelajaran yang masih global membuat sebagian masyarakat yang masih memiliki paham bahwa semua agama itu sama. Hal tersebut tidak sesuai dengan prinsip ajaran Agama Islam.

e. At Tasamuh

Sifat toleransi terhadap sesama, dengan sikap ramah dan menghargai pendirian orang lain seperti menghargai pendapat yang berbeda, menghargai pandangan yang bertentangan, menerima kepercayaan yang berlainan, memberikan kesempatan terlaksananya kegiatan dan tradisi yang bisa mengganggu. Semua itu terjadi dan dilakukan oleh masyarakat Laban.

Toleransi ini masih terjadi perbedaan persepsi dalam praktik pelaksanaannya dalam kegiatan keagamaan. Sebagian masyarakat ada yang sebatas memberikan kesempatan kepada warga agama lain untuk melaksanakan kegiatan keagamaannya, sebagian yang lain ada yang sampai ikut terlibat dalam kegiatan. 
Sikap ta'awun atau tolong menolong merupakan bukti kongkrit adanya nilai multikulturalisme. Karena keragaman kultur di sebuah daerah ketika belum ditunjukkan dengan adanya sikap saling menolong masih meninggalkan pertanyaan, benarkah masyarakat sudah bisa menerima kehadiran kultur yang berbeda. Dengan adanya tolong menolong membuktikan warga masyarakat sudah menerima kehadiran kultur lain dengan apa adanya.

Di desa Laban ditemukan banyak sikap tolong menolong masyarakat terhadap sesama. Tolong menolong di desa Laban ini tidak hanya terjadi antara sesama pemeluk agama. Baik yang sifatnya saling menguntungkan, bales budi, atau pertolongan murni.

g. Al Ikhtilaf (berbeda kebijakan)

Nilai multikulturalisme diantaranya adalah nilai perbedaan. Perbedaan yang tidak berujung pada perpecahan karena tindakan kekerasan. Hal ini akan bisa terwujud jika perbedaan tersebut disikapi dengan kebijaksanaan.

Jika kita melihat ke dalam desa Laban akan kita temukan keragaman budaya, agama, tradisi, kegiatan, pilihan jalan hidup dan lain-lain. Semuanya itu berjalan dengan baik tanpa terjadi persinggungan yang berarti. Bahkan ada yang saling mendukung, tolong menolong dan melengkapi dalam menjalani kehidupan. Melihat kenyataan yang terjadi, ini membuktikan bahwa nilai-nilai multikulturalisme sudah tertanam di dalam benak masyarakat.

Dari paparan data yang terkait dengan multikulturalisme ditemukan adanya penanaman kesamaan hak dalam menjalani kehidupan yang berhubungan dengan lima maqasid sari'ah. Menjaga agama, menjaga nyawa, menjaga harta, menjaga keturunan dan menjaga akal, dengan cara memberikan materi melalui pengajian atau pelajaran sekolah dan juga pemberian contoh perilaku dalam menjalani interaksi sosial sehari-hari atau sikap orang tua maupun tokoh masyarakat yang menunjukkan kelonggaran dalam memberikan kesempatan menjalin hubungan sosial masyarakat.

Pendidikan multikultural masyarakat Laban lebih cenderung dengan meniru budaya yang sudah ada dengan meniru perilaku dan cara interaksi generasi sebelumnya. Meskipun tidak terdapat aturan dan penekanan untuk saling menghormati, memberikan kesamaan hak, memberikan kebebasan, namun hal itu sudah dilakukan dalam interaksi sosial masyarakat dan bisa ditiru oleh generasi muda dan anak.

Keseimbangan antara pendidikan melalui tekstual dengan kontekstual yang belum berimbang, berpengaruh dalam beberapa kegiatan 
atau kebijakan sebagian masyarakat yang tidak sesuai dengan ajaran Pendidikan Agama Islam. Masyarakat lebih cenderung menggunakan pendekatan pragmatisme. Ketika menurut akal mereka menganggap baik maka akan dilaksanakan tanpa melihat teks ajaran agama.

Pemahaman pendidikan melalui perilaku dan pemberian contoh dari realitas akan menghasilkan pengertian yang realistis, namun dalam bentuk global dan belum terdapat penjelasan yang rinci, sehingga menghasilkan kesimpulan yang beragam, tergantung kemampuan aktor yang menafsirkan. Sedangkan pemahaman pendidikan melalui penyampaian materi sesuai literatur akan menghasilkan pengetahuan teoritis, belum menjamin sesuai dalam implementasinya dalam realita. Apabila dalam pengembangan pendidikan yang dilaksanakan melalui pemahaman rasional, maka akan menghasilkan pengetahuan liberal. Sedangkan pengembangan pendidikan yang dilaksanakan melalui pemahaman tekstual tanpa mempertimbangkan realitas yang terjadi akan menghasilkan pengetahuan literal dan cenderung radikal. Sehingga perlu untuk menyeimbangkan antara tekstual dan kontekstual untuk menghasilkan pengembangan pendidikan yang moderat.

\section{KESIMPULAN}

Pendidikan Agama Islam multikultural dalam interaksi sosial akan lebih baik apabila pembudayaan interaksi sosial mempertimbangkan tekstual dan kontekstual. Karena pengembangan pendidikan yang dilaksanakan hanya berdasarkan tekstual akan menghasilkan pengetahuan teoritis, belum menjamin sesuai dalam implementasinya dengan realita. Pengetahuan tersebut sebatas pengetahuan literal dan berpotensi radikal. Sementara pengembangan pendidikan yang dilaksanakan hanya berdasarkan realitas kehidupan tanpa mempertimbangkan tekstual dan hanya menggunakan rasional, maka berpotensi melahirkan pemahaman liberal. Dengan demikian, untuk menghasilkan pendidikan yang moderat maka pembelajaran behavioristik harus mempertimbangkan antara teks dan konteks.

\section{DAFTAR PUSTAKA}

Ahmadie Thoha, 2011, Muqaddimah Ibn Khaldun, terjemah. Jakarta: Pustaka Firdaus.

John W. Creswell, 2013, Penelitian Kualitatif \& Desain Riset. Yogyakarta: Pustaka Pelajar.

Khairuman, 2014, Model Pendidikan Inklusif, Jakarta: Mahisa Media Utama.

Lexy J Moleong, 1999. Metodologi Penelitian Kualitatif. Bandung: Remaja Rosdakarta. 
Moh Yamin, Vivi Auliya. 2011, Meretas Pendidikan Toleransi, Plurasisme dan Multikulturalisme Keniscayaan Peradaban. Malang: Madani Media.

Muhaimin. 2009, Wacana Pengembangan Pendidikan Islam. Yogyakarta: Pustaka Pelajar.

Muhammad Tholchah Hasan, 2016, Pendidikan Multikultural Sebagai Opsi Penanggulangan Radikalisme. Malang: Lembaga Penrbitan UNISMA.

Robert C. Bogdan dan Sari Knopp Biklen. 1998, Qualitative Research for education: An Introduktion to Theory and Methods. Boston: Alyn and Bacon, Inc.

Sugiono. 2007, Metode Penelitian Pendidikan Pendekatan Kuantitatif, Kualitatif dan RAD. Bandung: Alfabeta.

Yaya Suryana dan A Rusdina. 2015, Pendidikan Multikultural, Konsep, Prinsip dan Implementasi. Bandung: Pustaka Setia. 